\title{
POST-APARTHEID CINEMA: A THEMATIC AND AESTHETIC EXPLORATION OF SELECTED SHORT AND FEATURE FILMS
}

Martin P. Botha ${ }^{1}$

University of Cape Town

\begin{abstract}
The revival in short filmmaking in post-apartheid cinema has thus far received little attention by academic scholars. The article is an attempt to describe, contextualise and analyse the highlights of South African short filmmaking by focusing on thematic and aesthetic developments in post-apartheid cinema. Hundreds of short fiction and nonfiction films have been made in South Africa since 1980. The themes of most of these films were initially limited to anti-apartheid texts, which were instruments in the anti-apartheid struggle. During the late 1980s and early 1990s short filmmakers have also explored themes other than apartheid, for example equal rights for gay and lesbian South Africans. Many short filmmakers have since 1994 experimented with form and aesthetics, as well as various narrative structures, including oral storytelling. Future studies of post-apartheid cinema need to take the revival of short filmmaking in South Africa into account. Exciting directorial voices (male or female, gay or heterosexual, and from various language groups) such as Garth Meyer, Dumisani Phakhati, Willem Grobler, Teboho
\end{abstract}

\begin{tabular}{|l|l|l|l|l|}
\hline Ilha do Desterro & Florianópolis & n 61 & p. 225- 267 & jul/dez 2011 \\
\hline
\end{tabular}


Mahlatsi, Justin Puren, Inger Smith, Johan Nel, Nina Mnaya and John Warner hold immense promise for future feature filmmaking in post-apartheid South Africa.

Keywords: Post-apartheid cinema, short filmmaking, aesthetics, anti-apartheid texts, oral storytelling, Marginalised communities.

\section{Historical context}

Although 1994 saw the birth of democracy in South Africa the South African film industry is much older, in fact, our great documentary film tradition dates back to 1896 and the South African War or Anglo Boer War. ${ }^{2}$ Surprisingly only a few books have been published regarding the history of one of the oldest film industries in the world and one of the largest on the African continent. Between 1910 and 2008, 1,434 features were made in South Africa (Armes). Approximately 944 features were made in the period between 1978 and 1992, as well as nearly 998 documentaries and several hundred short films and videos (Blignaut and Botha).

South African film history is captured in a mere thirteen books. Developments in early South African cinema (1895-1940) have been chronicled in Thelma Gutsche's The History and Social Significance of Motion Pictures in South Africa 1895-1940 (1946/1972). Other significant studies include Keyan Tomaselli's Cinema of Apartheid: Race and Class in South Africa (1989), Johan Blignaut and Martin Botha's Movies Moguls Mavericks: South African Cinema 1979-1991 (1992), Martin Botha's edited volume, Marginal Lives and Painful Pasts: South African Cinema After Apartheid (2007), Jacqueline Maingard's South African National Cinema (2007), André Le Roux and Lila Fourie's Filmverlede: Geskiedenis van die Suid-Afrikaanse speelfilm (1982), Peter Davis's In Darkest Hollywood: Exploring the Jungles of Cinema's South Africa (1996), Martin Botha and Adri van 
Aswegen's Images of South Africa: The rise of the alternative film (1992), Tomaselli's compilation of revised and reworked papers and chapters published elsewhere, Encountering Modernity: Twentieth Century South African Cinemas (2006), Isabel Balseiro and Ntongela Masilela's edited volume, To Change Reels: Film and Film Culture in South Africa (2003), as well as Lucia Saks's Cinema in a democratic South Africa: The Race for Representation (2010).

During the 113 year history of South African cinema only two books have been devoted to South African film directors: Martin Botha and Hubert Dethier's Kronieken van Zuid-Afrika: De films van Manie van Rensburg (1997) and Martin Botha's Jans Rautenbach: Dromer Baanbreker en Auteur (2006a). Veterans such as Jans Rautenbach (Jannie Totsiens, 1970), Ross Devenish (Marigolds in August, 1980), Manie van Rensburg (The Fourth Reich, 1990) and the younger generation of the 1980s challenged moral and political censorship during apartheid, a severe lack of audience development and inadequate film distribution to shape progressive texts, which became the foundation of a new, critical South African cinema during the 1990s. ${ }^{3}$

The year 1994 could be regarded as a landmark for the South African film industry due to the historic democratic elections and the birth of a post-apartheid society. A comprehensive study by the research institution, the Human Sciences Research Council (HSRC), into the restructuring of the entire South African film industry was completed and forwarded to the Department of Arts, Culture, Science and Technology (Botha et al. 1994). The report of four hundred pages received widespread praise throughout the local film and television industry, especially by members of the Film and Television Federation (FTF) (Botha). The HSRC research team recommended that state aid to the local film industry should be 
administered by a statutory body referred to as the South African Film and Video Foundation (SAFVF). Commercial viability should not be the sole criterion for government support of locally made films. All types of films, including short films, ${ }^{4}$ should benefit, and a developmental fund should be used to support first-time filmmakers from previously marginalised communities.

The South African Minister of the Department of Arts, Culture, Science and Technology, Dr Ben Ngubane, formalised an Arts and Culture Task Group (ACTAG), in August/September 1994, to counsel him on the formulation of policy for the newly established government. In November of 1995, four months after the final ACTAG document was published, Dr Ngubane appointed a Reference Group to write up the Film Development Strategy document. This Reference Group comprised fourteen disparate members: individuals from the film industry; academics such as Keyan Tomaselli; the head of the HSRC research study into the film industry, Martin Botha, as well as Beschara Karam. The Reference Group met over a period of four weeks to discuss the drafting of the document, using the ACTAG document as the foundation for this paper. The first draft of the Film Development Strategy document appeared at the beginning of 1996, and a revised version was published later in the year. The writers proposed that the South African film and video industry be administered by a Statutory Body, known as the South African Film and Video Foundation (SAFVF). ${ }^{5}$

The rest is history. Thanks to the efforts of ACTAG and the writers of the White Paper the National Film and Video Foundation (NFVF) was finally established by the end of the 1990s. One of the long-term aims of the Foundation is to facilitate the placement of the South African film industry on a sound commercial footing and enable it to become internationally competitive. ${ }^{6}$ Despite the fact 
that the White Paper was an uneasy blend of progressive and neoliberal thinking it remains a valuable document, which gave birth to a national film commission (Balseiro and Masilela; Saks). ${ }^{7}$

In March 1995, the old South African film subsidy system, which was based on box office returns, ceased to exist, and an interim film fund became in operation. ${ }^{8}$ Ten million rand were annually distributed among various projects, which included funding for short filmmaking. In 1998, for example, R110,000 was allocated to the development of short films and R1.010,000 for the actual production of short films. During 2000 the National Film and Video Foundation (NFVF) started to support the local film industry, including short filmmaking. ${ }^{9}$

The revival in short filmmaking in South African cinema has thus far received little attention by academic scholars. Among the abovementioned books on South African film history only Botha (Marginal) and Maingard (157-166) focused on a significant development in recent South African cinema. Hundreds of short fiction and nonfiction films have been made in South Africa since 1980. The themes of most of these films were initially limited to anti-apartheid texts, which were instruments in the anti-apartheid struggle (Botha, "South Africa"). Since the late 1980s and early 1990s short filmmakers have also explored themes other than apartheid, for example equal rights for gay and lesbian South Africans. Many short filmmakers have since 1994 experimented with form and aesthetics, as well as various narrative structures, including oral storytelling. The article is an attempt to describe, contextualise and analyse the highlights of South African short filmmaking by focusing on thematic and aesthetic developments in post-apartheid cinema. Since thematic developments such as a cinema of marginal characters are not restricted to short films several features and documentaries have also been referenced in the text. 


\section{Short filmmaking during the 1980s and early 1990s}

Since the 1980s various short films portrayed events which were conveniently left out of official South African history books and of a contemporary context in actuality programmes on national television under control of the apartheid regime. Therefore, they became guardians of popular memory within the socio-political process in South Africa. Some of these films portrayed the forced removals of communities from their places of birth under the laws of apartheid. In Dear Grandfather your right foot is missing (1984), for example, director Yunus Ahmed created an imaginative and lyrical film about the destruction of Cape Town's District Six. ${ }^{10}$ Ahmed returned to the bulldozed landscape of his place of birth and through innovative film techniques, he evocatively recalled the spirit of the formerly thriving community. Set to the haunting sounds of Jean Michel Jarre, the endless tracking shots mercilessly explored the desolate plains, as if filmic interrogation would restore this place to its former life. The film became a lyrical lament for a lost area lying on the right foot of Table Mountain (the grey old Grandfather of Cape Town).

Acclaimed director Ross Devenish also made a short film about the movement of a family under apartheid's racial laws. In A chip of glass ruby (1982) the Banjee family lived in a small house in an area of Johannesburg which was reclassified as a white residential area. Although the family had lived there all their lives, they were forced to relocate to a new Indian development. In Cato Manor: people were living there (1989) director Charlotte Owen created a visually exciting, revealing and visually stunning history of Cato Manor, which was changed from a thriving and bustling active township of mixed African and Indian people to become its present unhappy ruin. Last supper at Horstley Street (1985) is a moving short documentary and true drama of one family's poignant experiences 
when they were removed from their traditional home in District Six and their attempts to adapt to their new environment, which was without amenities or traditions.

One of the most moving explorations of popular memory is Lance Gewer's Come see the bioscope (1984), a film about Sol Plaatje and his attempts at the beginning of this century to educate rural blacks about the Land Act of 1913. The film resembled the oral narrative structures of West African cinema (for example Wend Kuuni from Burkina Faso).

In 1989 Melanie Chait's Out in Africa became the first South African film to deal with the struggle for equal rights for gays and lesbians in South Africa. This short film is a moving tribute to two gay South African men, Simon Nkoli and Ivan Toms, who were respected internationally for their stand against apartheid. Dr Toms was the first white South African to refuse to serve in the South African Defence Force; Simon Nkoli was one of the Delmas trialists. The film portrayed what it meant to be gay under apartheid and claimed that the South African liberation struggle is a movement for political as well as gay equality.

An important new voice in the creation of a South African gay and lesbian cinema is Luiz DeBarros. Most of his early short films were screened at the short film competition of the Weekly Mail Film Festival. DeBarros was a third-year BA student at the University of the Witwatersrand when he made Pretty boys (1992), a film about two male prostitutes discussing their lives. The film attempted to explore the possibility of prostitution as a positive experience. Clubbing (1994) revolved around six 20-something-year-old friends who meet one evening before they go out clubbing. In the film DeBarros captured the decline of a white ruling class in a society in which the rules were changing. They must come to terms with a future of uncertainty, a 
future no longer assured of privilege. His film, Hot legs (1994), is a revenge fantasy which revolves around Tim, a young gay doctor who wants to take revenge on Dave, a man he once loved, by holding him captive in a motel room for six days. Together the two characters relive their past and look at how they became the people they are. It deals with the homophobic character of South African society. ${ }^{11}$

During the late 1980s the annual Weekly Mail film festival became an important forum for the screening of short films. A short film competition also encouraged new and young filmmakers to present their work at this festival. In the early 1990s short films about socio-political changes in South Africa and how people relate to them have become thematically dominant at this festival. In the 1980s the contours of South Africa's political landscape were transformed by massive black popular protest and government promises of a 'new' South Africa. Between black political mobilisation and a state attempting to manage a disintegrating economy existed another reality -- an embattled white working class struggling to defend a way of life in the face of loss of privilege based on race. Against this background, Guy Spiller's short film The Boxer (1990) explored the effect which wider socio-political changes in South African society had wrought in the intimate space of a white working-class family in Johannesburg. In particular, the film documented the hopes and fears of a young champion boxer in a society where the passage from youth to manhood involves entry into a world moulded by a violently defensive culture which is bound by a narrow patriotism and captured by the rhetoric of right-wing politicians.

One of the most remarkable films about adapting to the sociopolitical changes in South Africa is Catherine Meyburgh's The Clay Ox (1993). This visually stunning film portrayed the brief meeting of 
two young Afrikaners at the foot of the Drakensberg. He is a pacifist who is fleeing from military conscription. She is an activist who is preparing a suicidal bomb attack on a military target in Pretoria. In a highly symbolic landscape Meyburgh addresses the patriarchal, repressive society under apartheid. White Afrikaner mythology is examined by using numerous symbols and references to (white) Afrikaner history.

Throughout the 1990s various developments within the South African film industry stimulated the production of especially short films, a significant development in the growth of the post-apartheid film industry. The pay-television station M-NET initiated a project entitled NEW DIRECTIONS to give talented first-time South African and other African filmmakers and scriptwriters a break into the film industry. By 1999 M-NET’s MagicWorks has completed 20 short films and two features. This project became a showcase for new talent in this country, and has led to some outstanding short films such as Come See the Bioscope, Angel and Salvation. First-time directors and screenwriters, some of them female and/or black, explored a diversity of themes. Director Khalo Matabane and scriptwriter Mtutuzeli Matshoba, for example, created an award-winning comedy Chikin Biznis about the vibrant South African informal economic sector, which provides millions of unemployed urban South Africans with alternative livelihood. Russell Thompson and Patrick Shai explored South Africa's culture of violence respectively in The Pink Leather Chair and Stray Bullet, while directors Dumisani Phakathi and Tamsin McCarthy highlighted intimate relationships against the background of the new South African democracy respectively in $A n$ Old Wife's Tale and Cry Me A Baby. Relevant social problems such as drug abuse (Stimulation) and abortion (The Apology) were also explored in these M-NET short films. 
Regional initiatives further encouraged short film production. The former Cape Film and Video Foundation ${ }^{12}$ and the South African Scriptwriters Association (SASWA) in collaboration with the National Department of Arts, Culture, Science and Technology funded three short films, entitled Kap an Driver, a beautiful exploration of racial relations in the "new" South Africa; On the Rocks, about an affluent white man's encounter with Cape Town's homeless people; and Stompie and the Red Tide, also about Cape Town's homeless. The Southern African International Film and Television Market (Sithengi), ${ }^{13}$ which was held annually in Cape Town until 2006, became an important forum for locally made features and short films

The year 1998 highlighted an important Pan-African short film initiative, called African Dreaming. The array of six short films was a major co-production, the first of its kind on the continent, which had drawn on talent from Mozambique, Namibia, Senegal, Tunisia, Zimbabwe and South Africa. International funding came from the South African Broadcasting Corporation (SABC), the Hubert Bals Fund in the Netherlands, Cable channel La Sept/Arte in France, YLE TV2 in Finland, HIVOS and NCDO in Holland, the CNC in France, the French Ministry of co-operation and Video Lab in South Africa. Deals and contracts were co-ordinated by one of South Africa's leading producers, Jeremy Nathan, through his company Catalyst Films. The South African film, Mamlambo, a love story between a black boy and a Chinese girl, gave first-time female and black director, Palesa Letlaka-Nkosi chance to direct a fiction film.

During the 1990s short filmmaking in South Africa finally received international acclaim. Among the other short films, Gavin Hood's The Storekeeper stood out. ${ }^{14}$ It is a devastating portrait of the culture of violence in South Africa. Without relying on dialogue Hood tells the story of an elderly man who owns a small, isolated 
shop in rural South Africa. After several burglaries he took the law in his own hands-with shocking consequences. Hood's film won as overall best short film at the Nashville Independent Film Festival. It also won the bronze for best dramatic short at the Houston International Film Festival

Ironically only a few directors in the M-NET series moved on to features, for example, Ken Kaplan (The Children and I) directed the award-winning black comedy, Pure Blood; Russell Thompson (The Pink Leather Chair) made the gangster movie, The Sexy Girls, and Zola Maseko (A Drink in the Passage) directed Drum.

\section{Thematic and Aesthetic concerns in post-apartheid short films}

Post-apartheid cinema in general is characterised by the emergence of new voices and a diversification of themes. An exciting generation of male or female, gay or heterosexual directors has emerged. Many films explore the realities of South Africa from various ethnic perspectives and soundtracks include several of South Africa's 11 official languages. One thinks of a new generation of filmmakers such as Zola Maseko (The Life and Times of Sara Baartman, Drum), Ntshavheni Wa Luruli (Chikin Biznis-The Whole Story, The Wooden Camera), Mark Dornford-May (U-Carmen eKhayelitsha, Son of Man), Gustav Kuhn (Ouma se Slim Kind), Rehad Desai (Born into Struggle, Bushman's Secret), Donovan Marsh (Dollars and White Pipes), Akin Omotoso (God is African, Rifle Road), David Hickson (Beat the Drum), Teboho Mahlatsi (Portrait of a Young Man Drowning, Yizo Yizo, Sekalli sa Meokgo), Dumisani Phakhati (Christmas with Granny, Waiting for Valdez), Ramadan Suleman (Fools, Zulu love letter), Maganthrie Pillay (34 South), Sechaba Morojele (Ubuntu's Wounds), Gavin Hood (A Reasonable Man, Tsotsi), Zulfah Otto Sallies (Raya, Don't Touch), Teddy 
Mattera (Max and Mona), Andre Odendaal (Skilpoppe), Tim Greene (Boy called Twist), Riaan Hendricks (A Fisherman's Tale), Khalo Matabane (Chikin Biznis, Conversations on a Sunday Afternoon), Jason Xenopoulos (Promised Land), Madoda Ncayiyana (The Sky in Her Eyes, A Child is a child), Portia Rankoane (Tsietsi, My Hero), Thabang Moleya (Portrait of a Dark Soul, Case 474), Willem Grobler (Considerately Killing Me), Louis du Toit (When Tomorrow Calls), Tristan Holmes (Elalini), Garth Meyer (Killer October, Bitter Water), Inger Smith (The One that fits inside the Bathtub, Love Poem), Harold Holscher (iBali, ' $n$ Sprokie), Neill Blomkamp (Alive in JHB), Dean Blumberg (Under the Rainbow, Black Sushi), John Warner (Note to Self), Brett Melvill-Smith (Tracks), Bryan Little (Tagging Toilets), Nina Mnaya (Life is Hard), Matthew Cowles (The Tooth Fairy) and Norman Maake (Soldiers of the Rock, Homecoming).

\section{Marginalised communities get a voice}

For the first time South African audiences are exposed to certain marginalised communities, such as the homeless in Francois Verster's remarkable documentary Pavement Aristocrats: The Bergies of Cape Town (1998), the Himbas of Kaokoland in Craig Matthew's Ochre and Water (2001), AIDS victims in Shouting Silent (2001), the gay subcultures of the fifties and sixties in The Man Who Drove With Mandela (1998) and the San Bushmen in the Foster Brothers' visual poem The Great Dance (2000).

A gallery of marginal lives is seen in a variety of features, documentaries and shorts:

Homelessness and poverty-Angel, The Wooden Camera, The Flyer, Under the Rainbow, Boy Called Twist, Stompie and the Red Tide, Pavement Aristocrats: The Bergies of Cape Town, Malunde, 
Hillbrow Kids, Faith's Corner, Tsotsi, Boesman and Lena, Tracks, Azure, Life is Hard.

AIDS orphans-Shouting Silent, The Sky in her Eyes, A Child is a Child, Lucky.

AIDS victims-Yesterday, It's My Life, Beat the Drum, Considerately Killing Me, Nkosi.

Gays and lesbians-Proteus, Property of the State: Gay men in the Apartheid military, The Man Who Drove With Mandela, Skilpoppe, Apostles of Civilised Vice.

"Cultures under threat"-Ochre and Water, The Great Dance.

Foreigners in South Africa and xenophobia: The Foreigner, Conversations on a Sunday Afternoon, A shadow of hope.

Victims of institutionalised violence during apartheid: Zulu Love Letter, Ubuntu's Wounds, Forgiveness, Red Dust, The Guguletu Seven, What happened to Mbuyisa?, Between Joyce and Remembrance, Betrayal, Drum.

Victims of colonial racism: The Life and Times of Sarah Baartman. Victims of child rape: And there in the Dust

Intellectually challenged youths and the community's discrimination: Ouma se Slim Kind

Victims of drug addiction: Ongeriewe

Marginalised communities finally have a voice in our postapartheid cinema. Over the past ten years one has observed the remarkable revival in short filmmaking. Among the M-Net New Directions series Barry Berk's lovely film on the homeless in Angel (1996) and Dumisani Phakati's poetic coming- of- age tales, Christmas of Granny (1999) and especially Waiting for Valdez (2002) tower above the other shorts. Berk's Angel focuses on a group of homeless people in Cape Town. By contrasting their desperate situation with the beauty of the city and its surroundings, Berk has created a very moving portrait of people living on the margin of South African society. Phakathi's Waiting for Valdez is a visually eloquent evocation of a twisted society seen through a child's eyes. Set against the backdrop of forced removals in the 1970s the film 
deals with the popular memory of many South Africans, who lived during that dark period. But the film is also a lyrical, poignant tale of a young boy torn between his love for his dying grandmother and the desire to sneak out for nightly street recitals, around a drum fire, of movies his friends have seen at the local cinema.

One of the most impressive recent short films, which examines the impact of AIDS on South African society is Willem Grobler's multi-award winning Considerately Killing $\mathrm{Me}$ (2005). Winner of Best South African Short (Newcomer) at the 2006 Apollo Film Festival the short is the tragic tale of love and loss. It takes an introspective look at the life of John, a young South African filmmaker who has to deal with issues common among young adults today. John is confronted with the unstable political climate of Southern Africa and the rest of the world on a daily basis. He struggles as the local film industry is difficult to break into, and in trying to escape from the harsh realities of this world he submerges himself in a sea of hedonism, which results in his HIV/AIDS condition.

An important milestone in feature filmmaking is Jack Lewis's Proteus (2003), the beginning of a visible gay/lesbian cinema in South Africa. Under apartheid gay and lesbian voices in film and television were also silenced. In a seven year study of the depiction of gays and lesbians in African, Asian and Latin American cinema Botha (2003b) has noted that homosexual experience is unique in South Africa, precisely because of our history of racial division and subsequent resistance. Our gay identities have been formed by a long history of racial struggle. Our gay identities were also deformed by an oppressive system, which classified us into those with freedom and those without. Apartheid legislated whom we were, where we could live, with whom could we associate, and even what kind of sex we could have. Asserting a lesbian and gay identity in South 
Africa became a defiance of the fixed identities-of race, ethnicity, class, gender and sexuality-that the apartheid system attempted to imposture upon all of us.

The notions of a gay identity in South Africa as a defiance of fixed identity is brilliantly articulated in Proteus. Based on a true story, it is a period film that raises issues still of enormous relevance today. Historian and filmmaker Jack Lewis was fascinated by a court record in the Cape Archives, dated 18 August 1735, giving judgement in the case of two Robben Island prisoners. Dutch sailor Rijkhaart Jacobsz and Khoe convict Class Blank received extreme sentences for what the court called 'the abominable and unnatural crime of Sodomy'. It is an extremely moving experience and forms part of a very small number of South African productions on homosexuality.

Despite a new constitution which prohibits discrimination against gays and lesbians, as well as a strong gay movement, our images of gay men and women are limited and still on the margin of the film industry. One ends up with less than twenty short films, a few documentaries, less than ten features with openly gay and lesbian characters and virtually no television programmes during the past hundred years of South African cinema!

\section{Confronting the past and the present}

Another important theme in post-apartheid cinema is how South Africans are dealing with the traumatic past and how they are adjusting to the dramatic socio-political changes in contemporary South African society.

Ubuntu's Wounds (2003) is a landmark in our post-apartheid cinema. While several local documentaries have dealt with the Truth and Reconciliation Commission, Sechaba Morojele's film is the first attempt outside documentary film making to examine the 
effectiveness of the process and it questions whether real forgiveness is possible in response to truly inhuman acts. And it is a considerable achievement to raise and examine these questions in less than thirtyfive minutes. The film also shows off Morojele as an actor's director, eliciting strong performances from his ensemble cast.

Zola Maseko's moving A Drink in the Passage (2002) is a powerful short film about a touching encounter between a white and a black man in South Africa during the 1960s. A celebrated black sculptor recalls the curious events, which led him to share a drink of brandy with a white family during the height of apartheid. It is a complex contemplation on the personal dimensions of enforced segregation and the power of art to transcend the divide.

The criminal past and leaving it behind is the theme of Zulfah Otto-Sallies's Raya (2001), a story of three generations of women, their struggles and reconciliation. It is a visually beautiful insight into a closed, conservative community not often reflected on our screens.

When Tomorrow Calls (2003) is an important short by a young graduate, Louis du Toit, from one of South Africa's film schools, the City Varsity School of Media and Creative Arts. In only eleven minutes the poetic and highly symbolic narrative depicts an old order of the apartheid years making way for a new dispensation of hope and reconciliation in the story of an Afrikaans boy and a Xhosa boy facing each other as human beings. Shot in Afrikaans and Xhosa the film also depicts an Afrikaner nuclear family clearly characterised by the absence of the mother, and a father belonging to the past and unable to assist his son to adjust to the changing sociopolitical landscape of a post-apartheid South Africa. These cultural indicators are surprisingly also present in the Afrikaans short films of a new generation of directors: Rudi Steyn's Senter (2003), J-H Beetge's Triomfeer (2002), Danie Bester's Skitterwit (2003) and 
Johan Nel's Swing Left Frank (2003). Despite working independently from each other, the same images of the Afrikaner nuclear family in a post-apartheid society appear in these exciting shorts, especially with regard to the absence of the Afrikaner mother! Nel argues that the prevailing doctrine currently appears that Afrikaner fathers are portrayed as patriarchal, aggressive and archaic, while mothers are marginal or absent and that black characters offer liberation (unpublished). In When Tomorrow Calls and Senter the implied message is that a new generation of Afrikaners must learn to cooperate with their black counterparts in order to fit in with the new South Africa.

Especially Johan Nel's work is important as deliberate deconstructions of the soothing images of white Afrikaners in the cinema of the 1970s. With a few exceptions Afrikaans language films ignored the socio-political turmoil of the period, as well as the realities experienced by black South Africans. Most Afrikaans language films communicated by means of obsolete symbols that had little multicultural communication value. They painted a one-sided and stereotypical portrait of the Afrikaner, leading to a misconception about who and what the Afrikaner was. Furthermore, the negative portrayal of blacks as a servant class in these films is a visual symbol of the deep-seated apartheid ideology. Nel has attempted to look at Afrikaners in all their ugliness and multi-facets: In a series of short films ranging from Malpit to his best, Swing Left Frank, the idealised image of the white Afrikaner is challenged and analysed in a critical manner. In Swing Left Frank (2003) Frank Nel is an ex-soldier, who is caught having sex with a black woman by his wife. She kicks him out of the house and he leaves with a caravan to visit his ex-army friend, who owns a caravan park at the coast. His friend suffers from post traumatic stress and delusionaly relives combat (Nel). While 
staying at the resort Frank encounters Nomvula, the water spirit, who ultimately liberates him from earthly possessions and offers him transcendence. At the end of the film he enters the ocean where Nomvula takes his hand. They disappear into the deep. Nel argues that it seems as if material possessions are representative of Afrikaner privilege, which burden men in the post-apartheid milieu. Nomvula operates as a potential signifier of an exotic black culture, which is foreign but alluring to Frank. The manner in which Frank experience transcendence through her, echoes a similar motif of the troubled Afrikaner finding emancipation by bonding with a black character as seen in When Tomorrow Calls.

Some of the most interesting features indeed deal with the response of the Afrikaner community to the new democratic South Africa. One of the most powerful features since 1994 deals with an estranged Afrikaner community of white supremacists. In stark (almost black and white images) Promised Land (2002) depicts desperate minorities who, trying to retain their apartheid ideologies in the face of a new, democratic South Africa, have retreated into self-inflicted isolation and marginalization. When I saw Promised Land for the first time, I realised that there has been a bifurcation within Afrikaner culture. There is a clear split between the "old" and the "new". Contemporary Afrikaners have been forced to make a choice after 1994. To choose between racial separation and assimilation and to acknowledge all the ideological ramifications that comes with that decision. Promised Land depicts both sides of this equation. It portrays the death of one era and the birth of another. In doing so Promised Land depicts the advocates of separatist ideology quite cruelly.

With the same expressionist brilliance Ken Kaplan uses black comedy and the horror genre in Pure Blood (2000) to look at a group of white supremacists, which are trying to revive the old order of 
the apartheid years. The images of Afrikaners in Pure Blood and Promised Land are an important alternative to the idealised portrait of Afrikaners in the Afrikaans escapist cinema of the 1970s.

One of the greatest features to emerge out of South Africa since 1994 is Katinka Heyns's Paljas (1997). The narrative occurs in the 1960s, when poverty amongst Afrikaners was a serious problem and the South African Railway a key mechanism in Afrikaner affirmative action (Shepperson and Tomaselli). This excellent Afrikaans drama follows the deterioration of an Afrikaner family isolated and shunned in the small community of Toorwater. Nothing seems to happen. Then a circus train loses its way and comes to rest in Toorwater, and a mysterious clown brings fresh magic to the stagnating family, but he also poses a threat to the rest of the community. Heyns brilliantly succeeds in creating a metaphor for the Afrikaner family's turbulent emotional, cultural and ideological journey from the darkness of apartheid back into the light of post-apartheid reconciliation (familial, cultural and political) (A fine analysis of this film is provided by Shepperson and Tomaselli, 337-8)

Post-apartheid features are also dealing overwhelmingly and by necessity with the lives of Black South Africans. Two examples on display at this festival are Chikin Biznis-The Whole Story (1998) and Hijack Stories (2001) Chikin Biznis, an internationally acclaimed film (Best Film at the Montreal Film Festival and Best Screenplay at FESPACO 1999), follows the fortunes and blunders of middle aged Sipho, who gives up his menial work at a Stock Exchange listed company to embark on a new venture: The lucrative trade of chicken business. Sipho not only faces stiff competition from others in this informal sector, but he has to deal with his family as well. Fats Bookholane deservedly won as Best Actor at FESPACO 1999. Surviving in the "informal sector", but in this case, in a milieu of 
crime, is also one of the themes of Oliver Schmitz's Hijack Stories. Completed in 2000 it took three years to get a theatrical release in South Africa, a fate faced by several of the post-apartheid features.

\section{An experimentation with form}

Film schools have become vital in a post-apartheid South African cinema to expose students to international cinema, as well as to focus on the technological, social, aesthetical and political highlights in the development of cinema in all its facets. Apart from skills training South African film schools have the responsibility to nurture new voices in an industry, which has a long history in which many voices were silenced-those from the black majority, women, gays and lesbians. ${ }^{15}$ Film is not only for getting bums on seats, but ALSO a means of self-expression by voices, which were silent during the apartheid years. Those voices could belong to blacks, women, gays and lesbians, and others, who never had the opportunity to express themselves in the cinema under apartheid.

Some award-winning short films from graduates should be mentioned here. At the $25^{\text {th }}$ Stone Awards Evening of the National Television and Video Association (NTVA) in 2003 Harold Holscher's short iBali not only picked up a Stone Award for overall excellence, but garnered craft awards for directing, acting, cinematography and animation. The film is a magnificent blending of magic realism and African mythology, with touches of the urban alienation of Michelangelo Antonioni (Holscher is an admirer of Zabriskie Point), the surrealism of Djibril Diop Mambety and the beautiful compositions of Stanley Kubrick. Holscher states that iBali "came from an idea of living one's heritage, one's culture" (Holscher 2003). He is fascinated by myths and fables, especially in the cinemas of Mambety and Kusturica. The plot of iBali conveys how African heritage is passed 
from generation to generation through the art of story telling. It is a mythical tale about a boy discovering the essence of water.

The film is one of the first from a local film school, which actually explores the possibilities of orality in South African film narrative. It aims at an indigenous mode of aesthetics and judged by the national and international recognition, seems to succeed. Ibali was selected for the $14^{\text {th }}$ African Film Festival in Milan and formed part of the best of the shorts compilation. It was also selected for the Commonwealth Film Festival in Manchester and also toured the United Kingdom as part of the best of the festival. It was invited to the $7^{\text {th }}$ Genova Film Festival, as well as the 2004 Cape Town World Cinema festival.

Holscher graduated from the CityVarsity School of Media and Creative Arts with a list of awards that testify to his talent. During 2002 his experimental musical narrative In Progress won awards for directing and the overall production. In the same year he received awards for ' $n$ Sprokie, another "fairytale like iBali", characterised by exquisite visuals (another craft award), shot on $16 \mathrm{~mm}$. Adapted from an Afrikaans story it tells the sad tale of a woman waiting for her son to return from the war in Angola, but he will never return and the war has been lost.

Another graduate of CityVarsity the twenty-six year old John Warner has so far won no less than eleven local awards for his short films, music videos and advertisements. His greatest achievement to date is a short entitled Note to Self (2001), which won Gold and a craft award for directing at the 2001 NTVA Stone Awards ceremony. The film was screened in the official Ten Years of Democracy in South Africa retrospective at the $7^{\text {th }}$ Genoa film festival and Warner was an invited guest.

Highly ambitious for a final year $35 \mathrm{~mm}$ student production Note to Self is a surreal, almost Lynchian glimpse of the traumatic past 
still haunting our present. Two stories, one about a young man who kidnapped a girl, the other about two lovers who intend to meet for a Valentine's dinner, are seamlessly integrated into a dreamlike narrative. It is also a textbook of intertextuality: In only 12 minutes references are made to Blue Velvet, The Cell, Wild at Heart and Natural Born Killers. But this postmodern piece remains Warner's own original vision and has been acknowledged as such by the juries, who gave him an award for his direction. Technically it surpasses the majority of final year student productions by local film schools. It was selected in 2003 as one of the Best of RESFEST Africa and was screened in Durban, Cape Town and Johannesburg to a very warm reception especially from young audiences. Wherever it was screened in Cape Town audiences were stunned by the tecnical quality and beauty of the surreal images. Note to Self displays another characteristic in Warner's body of work, namely the deliberate subversion of movie genres. Throughout his shorts Warner played around with genre conventions and making references to various film examples.

Equally impressive is Killer October (2004) by Garth Meyer, also a graduate of the CityVarsity. By means of stunning visuals and an evocative sound design Meyer tells the story of a young boy, who loses a loved one due to an unknown disease. The film hints at AIDS, which currently ravages Zimbabwe and could be the "killer" of the title. The boy embarks on a mythical journey to find a resting place for the ashes of his parent. Documentary and African myth are impressively integrated in this short, which had its South African premiere at the Apollo Film festival in Victoria West, where it won Best South African short film, and its African premiere at Zanzibar during 2005.

Meyer's Bitter Water (Marah) is even more impressive than Killer October. The thirty-seven minutes short explores the link between 
old beliefs in supernatural forces and modern social deterioration as a result of failing morals in a rural community. The approach is magical realism. Two parallel plots involve a boy's story of revenging his sister's death and the more subliminal story of the inyanga's power to "make" a child for himself by using his powers. Oral storytelling is vividly explored.

Oral storytelling in recent short filmmaking has reached an aesthetic peak in Teboho Mahlatsi's Sekalli Le Meokgo (Meokgo and the Stickfighter) (2007). Visually ravishing this innovate short tells the story of Kgotso, a reclusive, concertina-playing stickfighter, who encounters the spirit of a beguiling woman, Meokgo, and rescues her from an evil horseman. Kgotso lives a solitary life high up in the Maluti Mountains of Lesotho. Whilst tending sheep and playing his concertina, he sees a beautiful and mysterious woman staring at him dreamily from the water. This story of unrequited love and sacrifice captures both the cruelty and the beauty of African magical beliefs. The film is in fact a fable that draws equally on Mozart's The Magic Flute and the living power of magic in traditional African cultures. Mahlatsi brilliantly uses bold, iconic images to build an elemental conflict worthy of a Sergio Leone western.

In recent animation shorts such as The Shadow Boy (2007) and The Mbulu's Bride (2006) by Justine Puren oral storytelling, African mythology and animation are creatively integrated. But any overview of the revival in short filmmaking is incomplete without a brief reference to an exciting animation cinema which has been emerging since the 1980s. The most important exponent is the artist William Kentridge. In Vetkoek fete galante, an animated silent film, Kentridge made fun of the State of Emergency of the 1980s. At the $12^{\text {th }}$ Durban International Film Festival four of his short animation films were presented under the title Animations by William Kentridge 
1978-1989. Kentridge used various techniques in creating these animation shorts. His Soho Eckstein saga depicts the battle between Soho Eckstein (property developer) and Felix Teitlebaum for the hearts and mines of Johannesburg. One of the shorts in the saga, Mine, subtly but scathingly indicts the mining industry. Monument, animated by means of a charcoal technique, chronicled the life of Soho as a civic benefactor. The whole saga has been assembled into a full-length feature film 9 Drawings for Projection, which was screened for the first time in South Africa in 2004.

\section{Conclusion}

More than five hundred short fiction and short non-fiction films have been made in South Africa since 1980. The themes of most of these films were initially limited to anti-apartheid texts. Since the late 1980s and early 1990s short filmmakers have also explored themes other than apartheid. The short films of the 1980s consisted mainly of images against apartheid, but later efforts were lyrical and sensitive portrayals of the destruction of indigenous cultures and forced removals of people due to apartheid laws. Some films also attempted to explore those aspects which were ignored in official history books. In the late 1980s, particularly because of the Weekly Mail Film Festival, new themes were explored in short films, such as gay and lesbian issues and attempts by people to adapt to changes in South Africa. Animation films, including those by William Kentridge, were also made. These short films form part of the new, critical South African film art which emerged in the second half of the 1980s.

Future studies of post-apartheid cinema need to take the revival of short filmmaking in South Africa into account. Exciting directorial voices such as Garth Meyer, Dumisani Phakhati, Willem Grobler, Teboho Mahlatsi, Justin Puren, Inger Smith, Johan Nel, 
Nina Mnaya and John Warner hold immense promise for future feature filmmaking in post-apartheid South Africa. Thanks to digital technology the post-apartheid cinema is currently enjoying a revival and substantial international acclaim. The industry, however, also faces major challenges. Despite the establishment of the National Film and Video Foundation (NFVF), local filmmakers are still struggling to find funding for their work, and in many cases, an audience for their films.

A film industry or in more ambitious terms, a national cinema, ${ }^{16}$ is ultimately dependent on the number of people who are willing to pay for it. Without a paying audience, whether it is cinema, television, video or new media exhibition, there can be no industry to speak of. With a total population of approximately forty-seven million people South Africa has a tiny cinema-going audience measured at approximately five million persons with a rapidly growing television consuming public penetrating approximately forty-nine percent of the total number of South African households. In the future audience development will become more and more crucial to build audiences for the post-apartheid cinema. Our film industry has been held to ransom for decades by the developed markets' funding and exhibition models, content and distribution strengths and worldwide dominance of the Hollywood studios (Botha "The Song"). It has been estimated that Hollywood product dominates ninety-nine percent of screen time in South African cinemas. Local filmmakers have to compete with films by independent American, British and Australian filmmakers, as well as "art-house" films from Europe, the Middle East and Asia for the remaining one percent.

Other challenges facing our industry are the inaccessible film exhibition sites that are outside the reach of the majority of South Africans, the limited concentration of theatres in metropolitan 
areas and the general lack of culturally specific, community based film exhibition points and product. According to research by the NFVF, audience attendance at South African cinemas is decreasing at an alarming rate to the extent that exhibitors have had to close down cinemas, especially in townships (Botha "The Song"). Some independent cinemas in townships have been converted to churches. Various factors contributing to this decline, including the increase in the range of entertainment media, especially a wider range of television content, door price increases, unemployment, crime, and a lack of effective marketing strategies.

Some theatrical distributors such as UIP (United International Pictures) owned by international studios merely serve as a "courier service" between the international studios and the local exhibitors. They do not have a quota system for local content distribution and exhibition and the rationale that informs their decision to acquire and to exhibit or NOT to acquire and exhibit product is based on the commercial viability of the product. Criteria used to determine viability is sometimes out of touch with South African and African realities, especially if one studies the cultural role of cinema within African communities. In this regard one could also look at the South Korean cinema regarding its struggle to fight American dominance. The unfair competition and massive marketing budgets of Hollywood studio backed film releases reduce the chances of South African boxoffice success at the cinema level. The introduction of incentivised screen quotas for domestic and African film theatric releases thus becomes a necessary intervention.

Through audience development programmes South African distributors and exhibitors can ultimately create a demand for local content on the screen, video hire, video sell thru, pay TV, free TV and public broadcasters, both locally and internationally. There 
is a definite need for aggressive marketing of South African films in people's home communities and the generation of local media enthusiasm around promotion of local product. Local film journalists and critics are also to be encouraged to support South African films. It is a fragile film industry, especially in the face of globalisation. The nurturing of new voices within our film industry will be of utmost importance if one would like to ensure the development of a postapartheid film industry, which is characterised by a vision of cultural diversity and an intention to empower the previously disadvantaged. Despite recent successes mentioned in the article, the economic viability, cultural diversity, as well as gender and racial inequality of the film industry remains a site of public concern (TreffryGoatley). At the 2009 NFVF Indaba Clarence Hamilton, Head of Production and Development at the NFVF, presented statistics on South African film production since 1994. A total of six hundred and fifteen documentaries were made from 1994 till 2008, with 2003 and 2004 as the most prolific years (154 productions). White directors still dominate production at sixty-eight percent compared to black directors at thirty-two percent. Male directors constituted the highest percentage at sixty-one percent compared to females at thirty-nine percent.

In addition to the NFVF's research results Kristin Pichaske's doctorate study on the process of racial transformation within South Africa's documentary film industry drew multiple conclusions. Thanks largely to the legacies of apartheid, the already high barriers to entry into the documentary field are considerably higher for people of colour in South Africa. For this and other reasons, black South Africans remain more often the subjects of documentaries than their makers. Overcoming this barrier must be a long-term priority, as it is the only means by which an equitable plurality of voices may reach 
South African audiences (Pichaske, unpublished). This persistence of racial inequity has fueled tensions throughout the film industry. In particular, white filmmakers who seek to document black subjects face mounting criticism, regardless of the purity of their intentions or methods. These tensions are ultimately a burden on the industry as a whole, and the inability to look past race has inhibited progress. Pichaske, however, argued that while racial parity must remain the film industry's ultimate goal, the intent, integrity, and approach of the filmmaker is ultimately a more significant determinant of representational accuracy than the colour of his or her skin. In particular, the following three factors are critical to accurate and ethical representation, regardless of the socio-economic status of the filmmaker vis-à-vis subject:

a. First-person and/or reflexive approaches to documentary storytelling which help frame documentary narratives as subjectivei.e. representations of one filmmaker's viewpoint as opposed to objective representations of pure, unadulterated fact.

b. The cultivation of meaningful relationships between filmmaker and subjects that endure beyond the scope of the project-the presence of which elevates the filmmaker's level of understanding and empathy toward his or her subjects, and also helps ensure a sense of responsibility for their long-term well-being.

c. Collaboration between filmmakers and subjects such that subjects have greater agency in determining the construction of their images. This strategy helps to mitigate both concerns regarding power imbalance, and inaccuracies that may arise through the practice of outsider storytelling.

With regard to feature film production the NFVF research department estimated that from 1994 till 2008 one hundred and thirty-two films were made. Representation of black directors is quite 
low at only fifteen percent compared to white directors at eighty-five percent. Representation of female directors is also quite low at only eighteen percent compared to male directors at eighty-two percent. A lot thus still needs to be done regarding the development of an economically sustainable post-apartheid cinema in which multiple, progressive and dynamic national identities are formulated and consumed by the majority of the population. Maybe it will require the complete replacement of apartheid's racially biased production and consumption infrastructure.

\section{Notes}

1. Dr Botha is an Associate Professor in the Centre for Film and Media Studies at the University of Cape Town. He published more than 200 articles, reports and papers on the South African media, including five books on South African cinema, namely Images of South Africa: the rise of the alternative film (1992), Movies Moguls Mavericks: South African cinema: 1979-1991 (1992), Kronieken van Zuid-Afrika: de films van Manie van Rensburg (1997) Jans Rautenbach: Dromer, baanbreker en auteur (2006) and Marginal Lives and Painful Pasts: South African cinema after apartheid (2007). He also co-wrote the White Paper for a post-apartheid film industry. He is currently working on a history of South African cinema for Intellect Books in Bristol.

2. A historical overview of South African documentary filmmaking between 1895 and 2007 is provided by Botha (2006c), as well as in a forthcoming publication entitled South African cinema: 1896-2010 (for Intellect Books).

3. The significant contribution of directors such as Rautenbach, Devenish and Van Rensburg has been explored in Botha (2006a, 2006b, 2006c, 2007), as well as Botha and Dethier (1997).

4. For the purpose of this article short films are defined as audiovisual material on film, video or DVD which is shorter than 60 minutes in duration.

5. The establishment of the NFVF and its role in the development of a post-apartheid film industry is documented by Botha (2003).

6. See Botha (2003). 
7. The impact of South African film policies on the national identity of the post-apartheid cinema was investigated by Astrid Treffry-Goatley in a PhD study at the University of Cape Town.

8. The former South African subsidy scheme is documented by Tomaselli (1989), Botha and Van Aswegen (1992), Blignaut and Botha (1992), as well as Botha $(2003,2004)$.

9. See Botha (2003).

10. District Six was a neighborhood inhabited mostly by coloureds and blacks, next to Cape Town's downtown area. The district was a hub of popular culture, being the cradle of a thriving musical community. In 1966, the government declared District Six a whites-only area under the Group Areas Act, with removals starting in 1968. By 1982, more than 60,000 people had been relocated to the sandy, bleak Cape Flats township complex some 25 kilometers away. The old houses were bulldozed. (Editor's note).

11. See Peach (2007) for the most comprehensive history yet of queer filmmaking in South Africa.

12. A new structure, the Cape Film Commission (CFC) was established during 1999.

13. Sithengi was later incorporated into the Cape Town World Cinema Film Festival.

14. Hood won an Oscar for the feature film Tsotsi (2006).

15. See Botha, M. P. "Homosexuality and South African cinema”. Kinema 19 (Spring, 2003): 39-64. The article provides a history of the oppression of gay voices in a cinema under apartheid.

16. Like the term "nation", "national cinema" is a complex and somewhat problematic term. This is mostly due to the fact that the concept of nationality varies according to different geographies, histories and cultures. The concept of a "National Cinema" is further compounded in the South African context where film industry fragmentation, a small production output and European and American monopolisation have resulted in claims that there "is no national cinema" to speak of (Botha 2004). 


\section{References}

Armes, R. Dictionary of African Filmmakers. Bloomington: Indiana University, 2008.

Balseiro, I. and Masilela, N. Eds. To change reels: Film and film culture in South Africa. Detroit: Wayne State University, 2003.

Blignaut, J. and Botha, MP. Eds. Movies Moguls Mavericks: South African cinema 1979-1991. Cape Town: Showdata, 1992.

Botha, M. P. "South African short filmmaking from 1980 to 1995: a thematic exploration”. Communicatio 22.2(1996): 51-56.

. "My involvement in the process which led to the White Paper on South African cinema". South African Theatre Journal 11.111 .2 (1997): 269-285.

. "Overview of South African cinema". De role van de media in de multiculturele samenleving. Eds. E. Schelfhout and H. Verstraeten. (Brussels: VUBPress, 1998).

"Current film policy in South Africa: the establishment of the National Film and Video Foundation of South Africa and its role in the development of a post-apartheid film industry". Communicatio 29.1 29.2 (2003a): 182-198.

. "Homosexuality and South African cinema". Kinema 19 (Spring, 2003b): 39-64.

. “The Song remains the same': The struggle for a South African film audience 1960-2003”. Kinema 21(Spring, 2004): 67-89.

. "New directing voices in South African cinema: Graduates from film schools". Kinema 23(Spring, 2005):5-21.

- Jans Rautenbach: Dromer, Baanbreker en Auteur. Cape Town: Genugtig! Publishers, 2006a. $5-26$.

"110 Years of South African cinema". Kinema 25(Spring, 2006b):

. “110 Years of South African cinema”. Kinema 26 (Fall, 2006c): 5-26.

. Ed. Marginal lives and painful pasts: South African cinema after apartheid. Cape Town: Genugtig! Publishers, 2007. 
. Mare, L., Langa, Z., Netshitomboni, R., Ngoasheng, K., Potgieter, J. and Greyling, M. Proposals for the restructuring of the South African film industry. Pretoria: Human Sciences Research Council, 1994.

. and Dethier, H. Kronieken van Zuid-Afrika: De films van Manie van Rensburg. Brussel: VUB Press, 1997.

. and Van Aswegen, A. Images of South Africa: The rise of the alternative film. Pretoria: Human Sciences Research Council, 1992.

Davis, P. In Darkest Hollywood: Exploring the jungles of cinema's South Africa. Randburg: Ravan, 1996.

Gutsche, T. The history and social significance of motion pictures in South Africa: 1895-1940. Cape Town: Howard Timmins, 1972.

Le Roux, A. and Fourie, L. Filmverlede: Geskiedenis van die Suid-Afrikaanse speelfilm. Pretoria: University of South Africa, 1982.

Louw, P. E. and Botha, J. R. "Film: the captivating power of fleeting images" Mass media for the nineties: the South African handbook of mass communication. Ed. A. S. de Beer. (Pretoria: Van Schaik, 1993): 151-172.

Maingard, J. South African National Cinema. Routledge: London, 2007.

Nel, R. The ambivalent rebellion: Tendencies in Afrikaner Counterculture. Unpublished Research Essay. Centre for Film and Media Studies, University of Cape Town, 2007.

Peach, R. "Skeef Cinema Entja: A brief history of South African queer cinematic cultures". Botha, M. P. ed. Marginal lives and painful pasts: South African cinema after apartheid. (Cape Town: Genugtig! Publishers, 2007): 51-87.

Pichaske, K. Colour Adjustment: Race and Representation in Post-Apartheid South African Documentary. Unpublished PhD thesis, University of Cape Town, 2009.

Saks, L. Cinema in a democratic South Africa: The race for representation. Bloomington, Indiana: Indiana University Press, 2010.

Shepperson, A. and Tomaselli, K. G. "South African cinema beyond apartheid: Affirmative action in distribution and storytelling". Social Identities 6.3 (2000): 323-324. 
. "Restructuring the industry: South African cinema beyond Apartheid". South African Theatre Journal 16 (2002): 63-79.

Tomaselli, K. The cinema of apartheid: race and class in South African film. New York: Smyrna, 1989.

. Encountering Modernity: Twentieth Century South African Cinemas. Pretoria: Unisa, 2006.

Treffry-Goatley, A. The representation and mediation of a national identity in the production of post-apartheid South African cinema. Unpublished PhD thesis, University of Cape Town, 2010.

\section{Acts \& Reports}

National Film and Video Foundation. Indaba 2001: Distribution, Exhibition and Marketing Report. Johannesburg: NFVF, 2001.

Nel, W. Profile 2000: Towards a viable South African Film Industry. Johannesburg: PricewaterhouseCoopers, 2000.

South Africa. National Film and Video Foundation Act. № 73 of 1997. Pretoria: Government Printer, 1997.

\section{Key short films 1980-2010}

1980

Shadowplay (Oliver Stapleton)

1982

Sales Talk (William Kentridge)

A Chip of Glass Ruby (Ross Devenish)

Country Lovers (Manie van Rensburg)

City Lovers (Barney Simon)

Good Climate, Friendly Inhabitants (Lynton Stephenson)

Praise (Richard Green) 
258 Martin P. Botha, Post-apartheid cinema: A thematic and aesthetic...

1984

The Mountain (Cedric Sundstrom)

Sales Talk (William Kentridge)

1986

The Hidden Farms (Ken Kaplan)

Getting off the Altitude (John Hookham)

The Stronger (Lynton Stephenson)

1998

The Burden (Ken Kaplan)

1990

Astor Mansions (Mark Wilby)

The Fridge (Robert Weinek)

Sacrifice (Aldo Lee \& Lance Gewer)

1991

$T \& I$ (William Kentridge)

1994

The Children and I (Ken Kaplan)

Come See the Bioscope (Lance Gewer)

1995

Corner Caffie (Tim Greene)

Eating Fish (Carsten Rasch)

Heartspace (Carey Schonegevel) 
1996

Angel (Barry Berk)

Stimulation (Andrew Worsdale)

The Pink Leather Chair (Russell Thompson)

1997

Chikin Biznis (Khalo Matabane)

Mamlambo (Palesa ka Letlaka Nkosi)

1998

Aces (Ntandazo Gcinga)

An Old Wife's Tale (Dumisani Phakathi)

The Foreigner (Zola Maseko)

Husk (Jeremy Handler)

Kap An Driver (Tim Greene)

Lucky Day (Brian Tilley)

Portrait of a Young Man Drowning (Teboho Mahlatsi)

The Storekeeper (Gavin Hood)

1999

Christmas with Granny (Dumisani Phakathi)

Home Sweet Home (Norman Maake)

Lefifeng Bofelong Balesedi (Norman Maake)

2000

Maar Nog 'n Dooie Veerverhaal (Nicola Hanekom)

2001

Angels en Boereoorloë (Vickus Strydom)

Note to Self (John Warner) 
260 Martin P. Botha, Post-apartheid cinema: A thematic and aesthetic...

Raya (Zulfah Otto-Sallies)

Triomfeer (Jan-Hendrik Beetge)

2002

Azure (Meg Rickards)

Down Under (Neil Sonnekus)

The Sky in her Eyes (Ouida Smit \& Madoda Ncayiyana)

Swing Left Frank (Johan Nel)

Ubuntu's Wounds (Sechaba Morejele)

Under the Rainbow (Dean Blumberg)

Waiting for Valdez (Dumisani Phakathi)

Western 4.33 (Aryan Kaganof)

When Tomorrow Calls (Louis du Toit)

2003

A Drink in the Passage (Zola Maseko)

Black Sushi (Dean Blumberg)

iBali (Harold Holscher)

Inja (Steve Pasvolsky)

Portrait of a Dark Soul (Thabang Moleya)

Senter (Rudi Steyn)

Skitterwit (Danie Bester)

2004

Case 474 (Thabang Moleya)

Ever Dark (Quinn da Matta)

Flight of the Feathers (Tristan Holmes)

Killer October (Garth Meyer)

Life is Hard (Nina Mnaya)

Lucky (Bobby Heaney) 
Modder Koffie (Brett Melvill-Smith)

The one that fits inside a Bathtub (Inger Smith)

$S A / X$ (Gilli Apter)

2005

Alive in Jhb (Neill Blomkamp)

Beyond Freedom: The South African Journey (Jacquie Trowell)

Bloedrooi (Quintin Wiehahn)

Considerating Killing $\mathrm{Me}$ (Willem Grobler)

Elalini (Tristan Holmes)

Escudo (Wolfgang Muller)

Fellini's Dreams-A documentary (Kelli Lakey)

Hollywood in My Huis (Corne van Rooyen)

Love poem (Inger Smith)

The Mamtsotsi Bird (Jo Horn)

Springbokkie (Lynette Mitchell)

Tracks (Brett Melvill-Smith)

2006

Bitter Water (Garth Meyer)

Blom (Gordon van der Spuy)

Bok (Bradshaw Schaffer)

Face Value (Gareth Bird)

The Mbulu's Bride (Justine Puren)

Milk (Jon Day)

Ongeriewe (Robin Kleinsmidt)

Sam had never seen her so sad (Anthony Silverston)

Spyker, Pine, Pool (Ruan Smith)

The Tooth Fairy (Matthew Cowles)

Take the Cakes (Stephen de Villiers) 
262 Martin P. Botha, Post-apartheid cinema: A thematic and aesthetic...

2007

At thy Call (Christopher Lee Dos Santos)

Beans and $a$ Friend (Rainer Leimeroth)

Begin (Jaco Kosie Smit)

Brothers in Arms 1978 (Dino Pappas \& Christopher Lee Dos Santos)

Commando (Stephen de Villiers)

Finale (Francois Coetzee)

Freedom Days (Quinton Lavery)

Kammakastig Land (Brandon Oelofse)

Karate Kallie (Willem van der Merwe)

Pondo Bicycle (Jan Ellis)

Sekalli Le Meokgo - Meokgo and the Stickfighter (Teboho Mahlatsi)

Sibahle (Joshua Roos)

Spaarwiel (Morne du Toit)

Réalou (Paul Speirs)

' $n$ Roos vir Mari (Louis du Toit)

Roses \& Lavender (Gareth H. Graham)

Service Pistol (Rio Allen)

The Shadow Boy (Justine Puren)

Vaderland (Desmond Denton)

2008

Breath (Mandilakhe Yengo)

Bury the Hatchet (Arthur Bacchus)

Elsie's Quota (Lee Ann Olwage)

Farm (Matthew Griffiths)

Finale (Francois Coetzee)

Friction (Aurora Drummer)

Jesus and the Giant (Akin Omotoso)

Hidden Places (Jamie Beron) 
Orgie (Hein Devos)

Painting Water (Kyle Davy)

The Resident (William Nicholson)

The Shadow Boy (Justine Puren)

Three Cigarettes (Stephen de Villiers)

Transactions (Thabang Moleya)

Uhambo (Josh de Kock)

Wide Open (Michael Matthews)

Winkletown (Imran Hamdulay)

2009

Greener Grass (Zaheer Goodman-Bhyat)

Homecoming (Kershan Pancham)

In a Time Without Love (Mark Strydom)

Out of Reach (Jade Ables)

Shaving Sheep (Carl Houston McMillan)

The Tunnel (Jenna Bass)

Unfinished Business (Graham Shillington)

Wamkelekile (Dorotea Vucic)

We are Home (Jessica Dawson)

Yolanda (Jo Horn)

2010

Father Christmas Doesn't Come Here (Bheki Sibiya)

The Abyss Boys (Jan-Hendrik Beetge)

Key features 1994-2010 ${ }^{1}$

1994

Cry the Beloved Country (Darrell Roodt)

The Making of the Mahatma (Shyam Benegal) 
264 Martin P. Botha, Post-apartheid cinema: A thematic and aesthetic...

1995

Nice to Meet You Please Don't Rape Me (Ian Kerkhof)

1996

Jump the Gun (Les Blair)

Fools (Ramadan Suleman)

1997

Paljas (Katinka Heyns)

The Sexy Girls (Russell Thompson)

1998

Chikin Bizniz - The Whole Story (Ntshaveni wa Luruli)

1999

A Reasonable Man (Gavin Hood)

2000

Hijack Stories (Oliver Schmidtz)

2001

Malunde (Stefanie Sycholt)

God is African (Akin Omotso)

Pure Blood (Kenneth Kaplan)

2002

Promised Land (Jason Xenopoulos)

2003

Beat the Drum (David Hichson) 
A Case of Murder (Clive Morris)

Proteus (John Greyson)

The Wooden Camera (Ntshaveni Wa Luruli)

Shooting Bokkie (Rob de Mezieres)

2004

In My Country (John Boorman)

The Story of an African Farm (David Lister)

Red Dust (Tom Hooper)

Hotel Rwanda (Terry George)

Drum (Zola Maseko)

Yesterday (Darrell Roodt)

Boy Called Twist (Tim Greene)

Max and Mona (Teddy Mattera)

2005

U-Carmen eKhayelitsha (Mark Dornford-May)

Zulu Love Letter (Ramadan Suleman)

The Flyer (Revel Fox)

Son of Man (Mark Dornford-May)

Faith's Corner (Darrell Roodt)

Tsotsi (Gavin Hood)

Dollars and White Pipes (Donovan Marsh)

2006

Ouma Se Slim Kind (Gustav Kuhn)

Don't Touch (Zulfah Otto-Sallies)

Conversations on a Sunday Afternoon (Khalo Matabane)

When We Were Black (Khalo Matabane) 
266 Martin P. Botha, Post-apartheid cinema: A thematic and aesthetic...

2007

Catch a Fire (Phillip Noyce)

Confessions of a Gambler (Amanda Lane \& Rayda Jacobs)

Goodbye Bafana (Bille August)

Meisie (Darrell Roodt)

More than Just a Game (Junaid Ahmed)

SMS Sugerman (Aryan Kaganof)

2008

Jerusalema (Ralph Ziman)

Gugu and Andile (Minky Schlesinger)

Land of Thirst (Meg Rickards)

My Black Little Heart (Claire Angelique)

Nothing but the Truth (John Kani)

Skin (Anthony Fabian)

Triomf (Michael Raeburn)

The World Unseen (Samim Sarif)

Zimbabwe (Darrell Roodt)

2009

Adera (Nega Tariku)

Crime-It's a Way of Life (Savo Tufegdzic)

Disgrace (Steve Jacobs)

District 9 (Neill Blomkamp)

Finding Lenny (Neal Sundstrom)

Long Street (Revel Fox)

My Secret Sky-Izulu Lami (Madoda Ncayiyana)

Shirley Adams (Oliver Hermanus)

Tornado and the Kalahari Horse Whisperer (Regardt van den Bergh)

White Wedding (Jann Turner) 
2010

The Bull on the Roof (Jyoti Mistry)

Jakhalsdans (Darrell Roodt)

Die Ongelooflike Avonture van Hanna Hoekom (Regardt van den Bergh)

I Now Pronounce You Black and White (Oliver Rodger)

Hopeville (John Trengove)

Jozi Kings (Jonathan Boynton-Lee \& Jamie Ramsay)

Life, Above All (Oliver Schmitz)

Machansa (Muntu Zwane)

Master Harold... and the Boys (Lonny Price)

Paradise Stop (Jann Turner)

A Small Town called Descent (Jahmil XT Qubeka)

Spud (Donovan Marsh)

State of Violence (Khalo Matabane)

Themba (Stefanie Sycholt)

* The name of the director is provided next to the title of the production.

[Received in 28/07/2011. Approved in 22/11/2011] 
